\title{
Efficacy of Botanicals and Essential Oils in the Management of Alternarial Leaf Spot of Ashwagandha (Withania somnifera L. Dunal)
}

\author{
M. Prashanth Kumar* and Sunil Zacharia \\ Department of Plant Pathology, Sam Higginbottom University of Agriculture, Technology and \\ Sciences, Prayagraj-211007, U.P., India \\ *Corresponding author
}

\begin{tabular}{|l|}
\hline Ke y w or d s \\
Alternaria leaf spot, \\
Ashwagandha, \\
Neem oil
\end{tabular}

Ashwagandha (Withania somnifera L. Dunal) is an important medicinal plant that is used in the Indian traditional system of medicine Ayurveda and Unani. It is affected by several fungal diseases. Out of these, Alternaria leaf spot causes $50-60 \%$ yield loss. In this present work, "Efficacy of botanicals and essential oils in the management of Alternarial leaf spot of Ashwagandha (Withania somnifera L. Dunal)" were studied with objective to study the effect of these in situ on disease intensity at 30, 60 and 90 DAT, plant height, root length, root dry weight. Among these treatments, neem oil $(1 \%)$ the most found effective in reducing disease intensity $(35.18 \%)$. whereas neem oil at $1 \%$ also showed maximum plant height $49.83 \mathrm{~cm}$, maximum root length $-19.95 \mathrm{~cm}$ and maximum root dry weight - $6.30 \mathrm{gm}$. The spray of botanical extracts and essential oils had reduced disease intensity of leaf spot and these essential oils can be exploited for the management of Alternarial leaf spot of Ashwagandha.

\section{Introduction}

Ashwagandha (Withania somnifera L. Dunal) is an important medicinal plant that is used in the Indian traditional system of medicine Ayurveda and Unani. Ashwagandha roots are compared with ginseng roots for their restorative properties and have been popularly known as Indian ginseng. It belongs to the family Solanaceae. It is an errect, evergreen, annual, drought resistant medicinal shrub growing to height of $30-150 \mathrm{~cm}$. The plant roots, leaves, fruits and seeds contain a number of alkaloids that is withanin and somniferine (Asthana and Raina, 1989). It is one of the most important herb of Ayurveda (the traditional system of medicine in India) used for millennia as a Rasayana for its wide 
ranging health benefits. In India, Ashwagandha is commercially cultivated in Madhya Pradesh, Gujarat, Maharashtra, Rajasthan, Haryana, Punjab, Karnataka and Uttar Pradesh. Ashwagandha is cultivated in more than 5000 hectare in the districts of Neemuch and Mandsaur (Madhya Pradesh), alone and in India it is cultivated under 10768 hectare land. In Aligarh district of Uttar Pradesh, Ashwagandha is cultivated in 950 hectares producing 4750 quintal of dried roots and 3.75 quintal of seeds. Ashwagandha is prone to several diseases and pests (Gupta et al., 1993, Nagraj and Reddy, 1985).

Under field conditions, the plants are damaged by viruses, mycoplasmas, bacteria as well as fungal pathogens. The two most destructive fungal pathogens of this plant are Alternaria alternata causing Alternaria leaf spot and Fusarium solani, causing fusarium wilt. Alternaria leaf spot causes $50-60 \%$ yield loss (Pati et al., 2008), whereas the yield loss due to fusarium wilt has been estimated by 55$65 \%$ (Bharti et al., 2013). The older and mature leaves are more susceptible to infection caused by Alternaria alternata.

Fusarium solani causes infection at seedling stage which sometimes results incomplete yield loss, however when the infection is caused at a later stage, no seed formation takes place or if formed, it is thin, tiny and shrivelled. The disease causes considerable damage to the plant during warm and humid climatic conditions.

For the management of alternarial blight of Ashwagandha, nowadays, increasing use of chemicals tremendously in agriculture has resulted in growing concern of both public health and environment hazards thus now emphasis is on use of indigenous sources and bio-agents for the management of the plant disease which is less costly and doesn't affect public health and environment.

\section{Materials and Methods}

The present study was conducted under the pot condition. Pot experiment was laid out in Completely Randomized Design (CRD) with three replications at research field of the Department of Plant Pathology, Sam Higginbottom University of Agriculture, Technology and Science, during the Rabi season of 2019-20.

\section{Appearance of disease}

The disease symptoms were noticed on the plant at 30-35 days after transplanting and per cent disease incidence was recorded at 30, 60 and 90 days after sowing.

\section{Isolation and Identification of the fungal organism}

Potato Dextrose Agar (PDA) was prepared and $80 \mathrm{mg}$ of streptomycin, an antibiotic was added to each $500 \mathrm{ml}$ preparation of the PDA to inhibit probable bacteria growth. Diseased portion of the leaves is cut under aseptic conditions into small bits into a sterile dish with the aid of scissors which is flamed over a spirit lamp flame and surface sterilized in 0.1 $\%$ mercuric chloride.

The cut diseased and surface sterilized bits with $70 \%$ ethanol was placed on petri dishes poured with solidified potato dextrose agar (PDA). The inoculated plates were incubated at room temperature until visible growths are seen on the plates. The fungal colonies growing in the incubated plates were subcultured into fresh medium until pure cultures are obtained.

Examination of the fungal colony characteristics was done through microscopic examination. Using a sterile needle, a small portion of the culture is taken and placed on a sterile glass slide. It is stained using 
lactophenol and cotton blue. Then, the microscope is used for the examination of morphology and culture characteristics of fungal structures.

\section{Characters of Alternaria alternata}

The fungus produces profuse mycelium growth on PDA. Initially, the mycelium was hyaline that turned to grey-brownish, multicelled, septate and irregularly branched.

In early growing stage, hyphae were thin (2.84 $\mu \mathrm{m}$ in diameter) narrow, hyaline but became slightly thick $(4.42 \mu \mathrm{m}$ in diameter) as they grew old. Conidiophores arise singly or in clusters, usually 2-6 and were long or short.

\section{Preparation of plant extracts}

The fresh leaf extracts are gently washed under running tap and finally in sterile distilled water. They were separately grinded in sterile water at the rate $1 \mathrm{mlg}^{-1}$ of plant material in pistal and mortal. Then it is stained through double layer of muslin cloth and finally through sterilized Whatman no.1 filter paper.

This forms $100 \%$ standard plant extract solution. Further its dilution was performed of required concentration with sterilized water. By grinding $10 \mathrm{gm}$ of leaves in $100 \mathrm{ml}$ of sterile water $10 \%$ of leaf extract was obtained.

\section{Preparation of essential Oil}

All the fresh leaves are collected and washed under the running tap water and introduced into the conical flask with alcohol and is plugged out. Then it is dried in direct sunlight for 3 days. After it is collected together and placed in soxhlet apparatus for the extraction of oil. Then the oil sample is preserved and kept in a sealed vial at $4^{\circ} \mathrm{C}$ until analysis.

\section{Per cent Disease Index}

Per cent Disease Index (\%) was recorded at 30, 60 and 90 days after incidence of Alternaria alternate.

The Per cent Disease Index (PDI) was worked out using Kinney MC (1923) formula i.e;

Disease intensity (\%)

Sum of all disease ratings

=-------------------------------------------x 100

Total number of $\times$ Maximum disease rating grade

\section{Results and Discussion}

\section{Disease Intensity (\%)}

\section{Disease intensity (\%) at 30 DAT}

The data presented in table 4.1 and depicted in figure 4.1 reveals that minimum disease incidence (\%) in Ashwagandha at 30 DAT was recorded in $\mathrm{T}_{5}$-Neem oil(3.21 \%) followed by $\mathrm{T}_{6}$ - Peppermint oil (4.03\%), $\mathrm{T}_{1}$ Neem leaf extract $(4.35 \%), \mathrm{T}_{3}$-Tulsi leaf extract(4.93\%), $\mathrm{T}_{2}$ - Parthenium leaf extract $(5.83 \%)$ and $\mathrm{T}_{4}$-Lantana camera $(6.67 \%)$ as compared to $\mathrm{T}_{7}-$ Mancozeb(treated) $(2.15 \%)$ and $\mathrm{T}_{0}$ - untreated checks (12.19\%). All the treatments were significant over control. Among the treatments $\left(\mathrm{T}_{7}\right.$ and $\left.\mathrm{T}_{5}\right),\left(\mathrm{T}_{5}, \mathrm{~T}_{6}\right.$ and $\left.\mathrm{T}_{1}\right),\left(\mathrm{T}_{6}, \mathrm{~T}_{1}\right.$ and $\left.\mathrm{T}_{3}\right),\left(\mathrm{T}_{1}\right.$ and $\left.\mathrm{T}_{3}\right)$ and $\left(\mathrm{T}_{3}\right.$ and $\left.\mathrm{T}_{2}\right)$ are statistically non- significant to each other.

\section{Disease intensity (\%) at 60 DAT}

The data presented in table 4.1 and depicted in figure 4.1 reveals that minimum disease incidence (\%) in Ashwagandha at 60 DAT was recorded in $\mathrm{T}_{5}$-Neem oil(12.97 \%) followed by $\mathrm{T}_{6}$-Peppermint oil $(13.83 \%), \mathrm{T}_{1}$ Neem leaf extract(15.77\%), $\mathrm{T}_{3}$-Tulsi leaf extract $(18.55 \%), \mathrm{T}_{2}$ - Parthenium leaf extract $(20.11 \% \%)$ and $\mathrm{T}_{4^{-}}$Lantana camera 
(21.57\%) as compared to $\mathrm{T}_{7}$ - Mancozeb (treated) $(11.57 \%)$ and $\mathrm{T}_{0^{-}}$untreated checks $(32.46 \%)$. All the treatments were significant over untreated control. Among the treatments $\left(\mathrm{T}_{7}\right.$ and $\left.\mathrm{T}_{5}\right)$ are statistically non- significant to each other.

\section{Disease intensity (\%) at 90 DAT}

The data presented in table 4.1 and depicted in figure 4.1 reveals that minimum disease incidence (\%) in Ashwagandha at 90 DAT was recorded in $\mathrm{T}_{5}$-Neem oil- $(35.18 \%)$ followed by $\mathrm{T}_{6}$ - Peppermint oil (37.22\%), $\mathrm{T}_{1}$ Neem leaf extract $(40.34 \%), \mathrm{T}_{3}$-Tulsi leaf extract(43.44\%), $\mathrm{T}_{2}$ - Parthenium leaf extract $(45.17 \%)$ and $\mathrm{T}_{4}$-Lantana camera $(45.95 \%)$ as compared to $\mathrm{T}_{7}$ - Mancozeb (treated) (28.18 $\%)$ and $\mathrm{T}_{0}$ - untreated checks $(68.27 \%)$. All the treatments were significant over untreated control. Among the treatments $\left(\mathrm{T}_{3}\right.$ and $\left.\mathrm{T}_{2}\right)$ and $\left(T_{2}\right.$ and $\left.T_{4}\right)$ are statistically non- significant to each other.

\section{Plant Height at harvest (cm)}

The data presented in table 4.2 and depicted in figure 4.2 reveals that maximum plant height in Ashwagandha at harvest was recorded in $\mathrm{T}_{5}$ -Neem oil $(49.83 \mathrm{~cm})$ followed by $\mathrm{T}_{6}$ Peppermint oil $(48.00 \mathrm{~cm}), \mathrm{T}_{1}$ - Neem leaf extract $(44.20 \mathrm{~cm}), \mathrm{T}_{3}$-Tulsi leaf extract $(43.00 \mathrm{~cm}), \mathrm{T}_{2}$ - Parthenium leaf extract $(39.47$ $\mathrm{cm})$ and $\mathrm{T}_{4}-$ Lantana camera $(38.33 \mathrm{~cm})$ as compared to $\mathrm{T}_{7}$ - Mancozeb (treated) (50.27 $\mathrm{cm})$ and $\mathrm{T}_{0^{-}}$untreated checks $(35.93 \mathrm{~cm})$. All the treatments were significant over untreated control. Among the treatments $\left(T_{2}\right.$ and $\left.T_{4}\right)$ and $\left(\mathrm{T}_{1}\right.$ and $\left.\mathrm{T}_{3}\right)$ are statistically non- significant to each other.

\section{Root length (cm) at harvest}

The data presented in table 4.3 and depicted in figure 4.3 reveals that maximum root length in Ashwagandha at harvest was recorded in $\mathrm{T}_{5}$ -
Neem oil $(19.95 \mathrm{~cm})$ followed by $\mathrm{T}_{6}$ Peppermint oil $(19.41 \mathrm{~cm}), \mathrm{T}_{1}$ - Neem leaf extract $(18.51 \mathrm{~cm}), \mathrm{T}_{3}$ - Tulsi leaf extract $(18.45 \mathrm{~cm}), \mathrm{T}_{2}$ - Parthenium leaf extract (18.07 $\mathrm{cm})$ and $\mathrm{T}_{4}$ - Lantana camera $(15.84 \mathrm{~cm})$ as compared to $\mathrm{T}_{7}-$ Mancozeb (treated) (20.16 $\mathrm{cm})$ and $\mathrm{T}_{0^{-}}$untreated checks $(15.24 \mathrm{~cm})$.

All the treatments were significant over untreated control. Among the treatments $\left(\mathrm{T}_{4}\right.$ and $\left.\mathrm{T}_{0}\right),\left(\mathrm{T}_{1}, \mathrm{~T}_{2}\right.$ and $\left.\mathrm{T}_{3}\right),\left(\mathrm{T}_{1}, \mathrm{~T}_{3}\right.$ and $\left.\mathrm{T}_{6}\right)$ and $\left(\mathrm{T}_{1}\right.$ and $\mathrm{T}_{6}$ ) are statistically non- significant to each other.

\section{Root dry weight (gm)}

The data presented in table 4.3 and depicted in figure 4.3 reveals that maximum dry weight of root in Ashwagandha at harvest was recorded in $\mathrm{T}_{5}$-Neem oil $(6.30 \mathrm{gm})$ followed by $\mathrm{T}_{6}-$ Peppermint oil $(5.40 \mathrm{gm}), \mathrm{T}_{1}$ - Neem leaf extract(5.10 gm), $\mathrm{T}_{3}$ - Tulsi leaf extract (4.80 $\mathrm{gm}), \mathrm{T}_{2}$ - Parthenium leaf extract $(4.40 \mathrm{gm})$ and $\mathrm{T}_{4^{-}}$Lantana camera $(4.10 \mathrm{gm})$ as compared to $\mathrm{T}_{7}$ - Mancozeb (treated) $(8.60$ $\mathrm{gm})$ and $\mathrm{T}_{0^{-}}$untreated checks (3.49 gm). All the treatments were significant over untreated control. Among the treatments $\left(\mathrm{T}_{0}\right.$ and $\left.\mathrm{T}_{4}\right)$, $\left(T_{4}, T_{2}\right.$ and $\left.T_{3}\right),\left(T_{2}, T_{3}\right.$ and $\left.T_{1}\right),\left(T_{3}, T_{1}\right.$ and $\left.T_{6}\right)$ and $\left(\mathrm{T}_{1}\right.$ and $\left.\mathrm{T}_{6}\right)$ are statistically nonsignificant to each other.

In the present experiment, the best results were obtained from Neem oil $\left(T_{5}\right)$ followed by the Peppermint oil $\left(\mathrm{T}_{6}\right)$. Similar findings are also reported by Rawat et al., (2017) and Franca et al., (2018). The active ingredients of Neem oil are mostly of triterpinoids, e.g., nimbin, nimbidine, azadirachtin etc. Neem contains varied chemical constituents such as nimolicinol, isolimolicinolide, azadirachtol, nimolinone, nimbocinol, nimocin, etc. (Brahmachari, 2004; Tewari, 1992). The azadirachtin component of Neem has been reported to be as effective as bavistin and mancozeb (Dubey et al., 2003). 
Table.1 Per cent disease incidence of leaf spot (Alternariaalternata) in Ashwagandha at 30, 60 and 90 DAT as affected by treatments

\begin{tabular}{|c|c|c|c|c|c|}
\hline S. No. & Treatment name & Conc. & $\begin{array}{l}30 \text { DAT } \\
(\%)^{*}\end{array}$ & $\begin{array}{c}60 \text { DAT } \\
(\%)^{*}\end{array}$ & $\begin{array}{c}90 \text { DAT } \\
(\%)^{*}\end{array}$ \\
\hline $\mathbf{T}_{\mathbf{0}}$ & Control (Distilled water spray) & & 12.19 & 32.46 & 68.27 \\
\hline$T_{1}$ & Neem leaf extract (Foliar spray) & $10 \%$ & $4.35^{\mathrm{bcd}}$ & 15.77 & 40.34 \\
\hline $\mathbf{T}_{2}$ & Parthenium leaf extract (Foliar spray) & $10 \%$ & $5.83^{\mathrm{e}}$ & 20.11 & $45.17^{\mathrm{ab}}$ \\
\hline $\mathbf{T}_{3}$ & Tulsi leaf extract (Foliar spray) & $10 \%$ & $4.93^{\mathrm{cbd}}$ & 18.55 & $43.44^{\mathrm{a}}$ \\
\hline $\mathbf{T}_{4}$ & Lantana camara leafextract (Foliar spray) & $10 \%$ & 6.67 & 21.57 & $45.95^{b}$ \\
\hline $\mathbf{T}_{5}$ & Neem oil (Foliar spray) & $1 \%$ & $3.21^{\mathrm{ab}}$ & $12.97^{\mathrm{a}}$ & 35.18 \\
\hline$T_{6}$ & Peppermint oil (Foliar spray) & $1 \%$ & $4.03^{\mathrm{bc}}$ & 13.83 & 37.22 \\
\hline \multirow[t]{3}{*}{$\mathbf{T}_{7}$} & Mancozeb (Foliar spray) & $0.2 \%$ & $2.15^{\mathrm{a}}$ & $11.57^{\mathrm{a}}$ & 28.18 \\
\hline & \multicolumn{2}{|l|}{ C. D. $(5 \%)$} & 1.36 & 1.45 & 1.88 \\
\hline & \multicolumn{2}{|l|}{ S. Ed. $( \pm)$} & 0.64 & 0.67 & 0.88 \\
\hline
\end{tabular}

*Average of three replications

Means followed by same letters in the column are non-significant to each other

Table.2 Plant height $(\mathrm{cm})$ of Ashwagandha as affected by treatments

\begin{tabular}{|c|c|c|c|}
\hline Sr. No. & Treatments & Conc. & $\begin{array}{c}\text { Plant Height } \\
(\mathbf{c m})^{*}\end{array}$ \\
\hline $\mathbf{T}_{\mathbf{0}}$ & Control (Distilled water spray) & - & 35.93 \\
\hline $\mathbf{T}_{\mathbf{1}}$ & Neem leaf extract (Foliar spray) & $10 \%$ & $44.20^{\mathrm{b}}$ \\
\hline $\mathbf{T}_{\mathbf{2}}$ & Parthenium leaf extract (Foliar spray) & $10 \%$ & $39.47^{\mathrm{a}}$ \\
\hline $\mathbf{T}_{\mathbf{3}}$ & Tulsi leaf extract (Foliar spray) & $10 \%$ & $43.00^{\mathrm{b}}$ \\
\hline $\mathbf{T}_{\mathbf{4}}$ & Lantana camaraleaf extract(Foliar spray) & $10 \%$ & $38.33^{\mathrm{a}}$ \\
\hline $\mathbf{T}_{\mathbf{5}}$ & Neem oil (Foliar spray) & $1 \%$ & 49.83 \\
\hline $\mathbf{T}_{\mathbf{6}}$ & Peppermint oil (Foliar spray) & $1 \%$ & 48.00 \\
\hline $\mathbf{T}_{\mathbf{7}}$ & Mancozeb (Foliar spray) & $0.2 \%$ & 50.27 \\
\hline & C.D. ( $\mathbf{5 \%}$ & & 1.25 \\
\hline & S. Ed. $\mathbf{( \pm )}$ & & 0.58 \\
\hline
\end{tabular}

* Average of three replications

Means followed by same letters in the column are non-significant to each other

Table.3 Root length $(\mathrm{cm})$ and root dry weight $(\mathrm{gm})$ of Ashwagandha at harvest as affected by treatments

\begin{tabular}{|c|c|c|c|c|}
\hline S. No & Treatment name & Conc. & $\begin{array}{c}\text { Root length } \\
(\mathbf{c m})\end{array}$ & $\begin{array}{c}\text { Root dry weight } \\
(\mathbf{g m})\end{array}$ \\
\hline $\mathbf{T}_{\mathbf{0}}$ & Control (Distilled water spray) & - & $15.24^{\mathrm{a}}$ & $3.49^{\mathrm{a}}$ \\
\hline $\mathbf{T}_{\mathbf{1}}$ & Neem leaf extract (Foliar spray) & $10 \%$ & $18.51^{\mathrm{bcd}}$ & $5.10^{\text {cde }}$ \\
\hline $\mathbf{T}_{\mathbf{2}}$ & Parthenium leaf extract (Foliar spray) & $10 \%$ & $18.07^{\mathrm{b}}$ & $4.40^{\mathrm{bc}}$ \\
\hline $\mathbf{T}_{\mathbf{3}}$ & Tulsi leaf extract (Foliar spray) & $10 \%$ & $18.45^{\mathrm{bc}}$ & $4.80^{\mathrm{bcd}}$ \\
\hline $\mathbf{T}_{\mathbf{4}}$ & Lantana camaraleaf extract (Foliar spray) & $10 \%$ & $15.84^{\mathrm{a}}$ & $4.10^{\mathrm{ab}}$ \\
\hline $\mathbf{T}_{\mathbf{5}}$ & Neem oil (Foliar spray) & $1 \%$ & 19.95 & 6.30 \\
\hline $\mathbf{T}_{\mathbf{6}}$ & Peppermint oil (Foliar spray) & $1 \%$ & $19.41^{\mathrm{cd}}$ & $5.40^{\mathrm{de}}$ \\
\hline $\mathbf{T}_{\mathbf{7}}$ & Mancozeb (Foliar spray) & & 20.16 & 8.60 \\
\hline & C.D. (5\%) & & 1.22 & 0.88 \\
\hline
\end{tabular}

* Average of three replications

Means followed by same letters in the column are non-significant to each other 
Fig.1 Effect of botanical extracts and essential oils on Percent Disease Index of Leaf spot of Ashwagandha

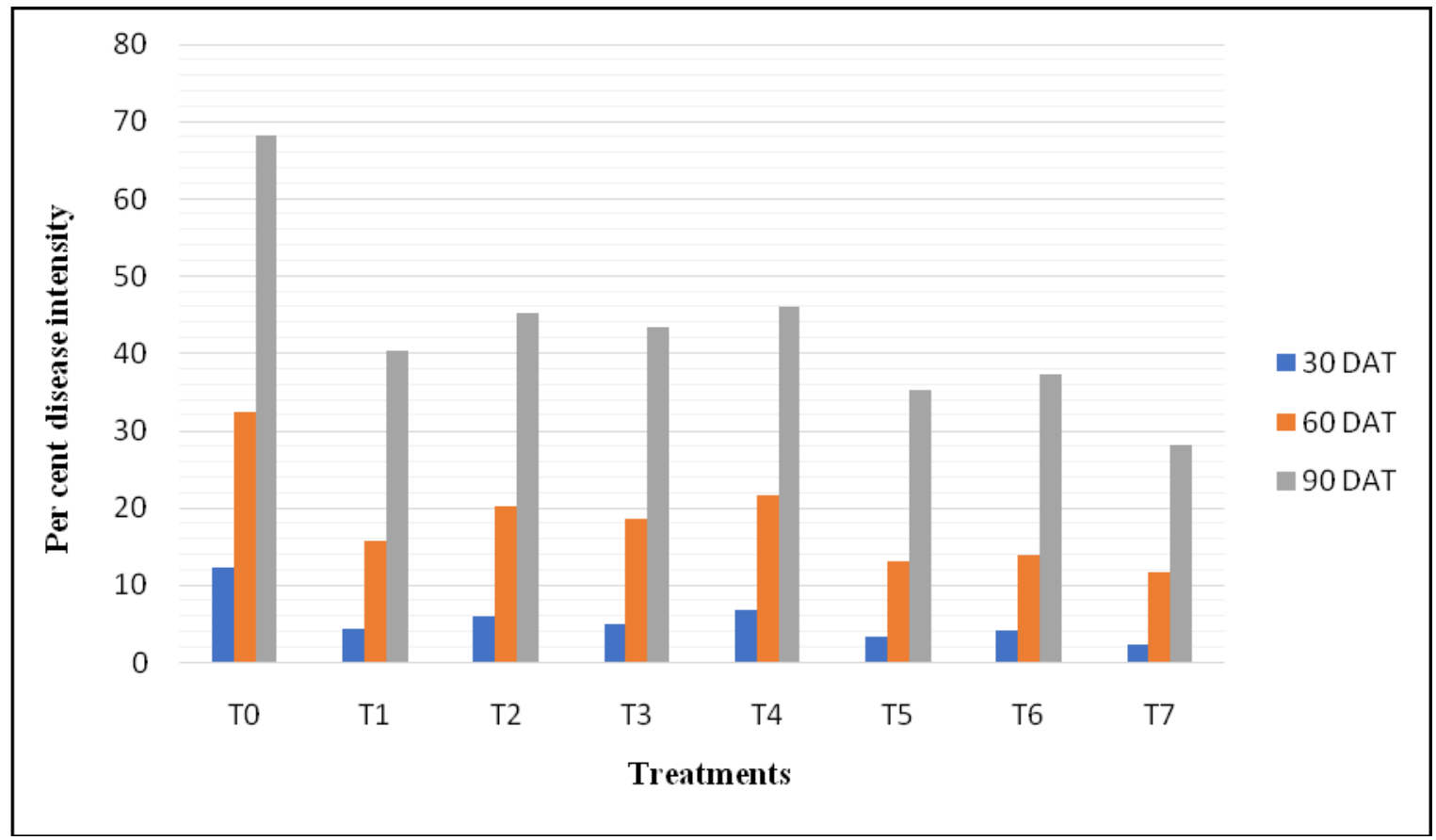

Fig.2 Effect of botanicals and essential oils on plant height of Ashwagandha

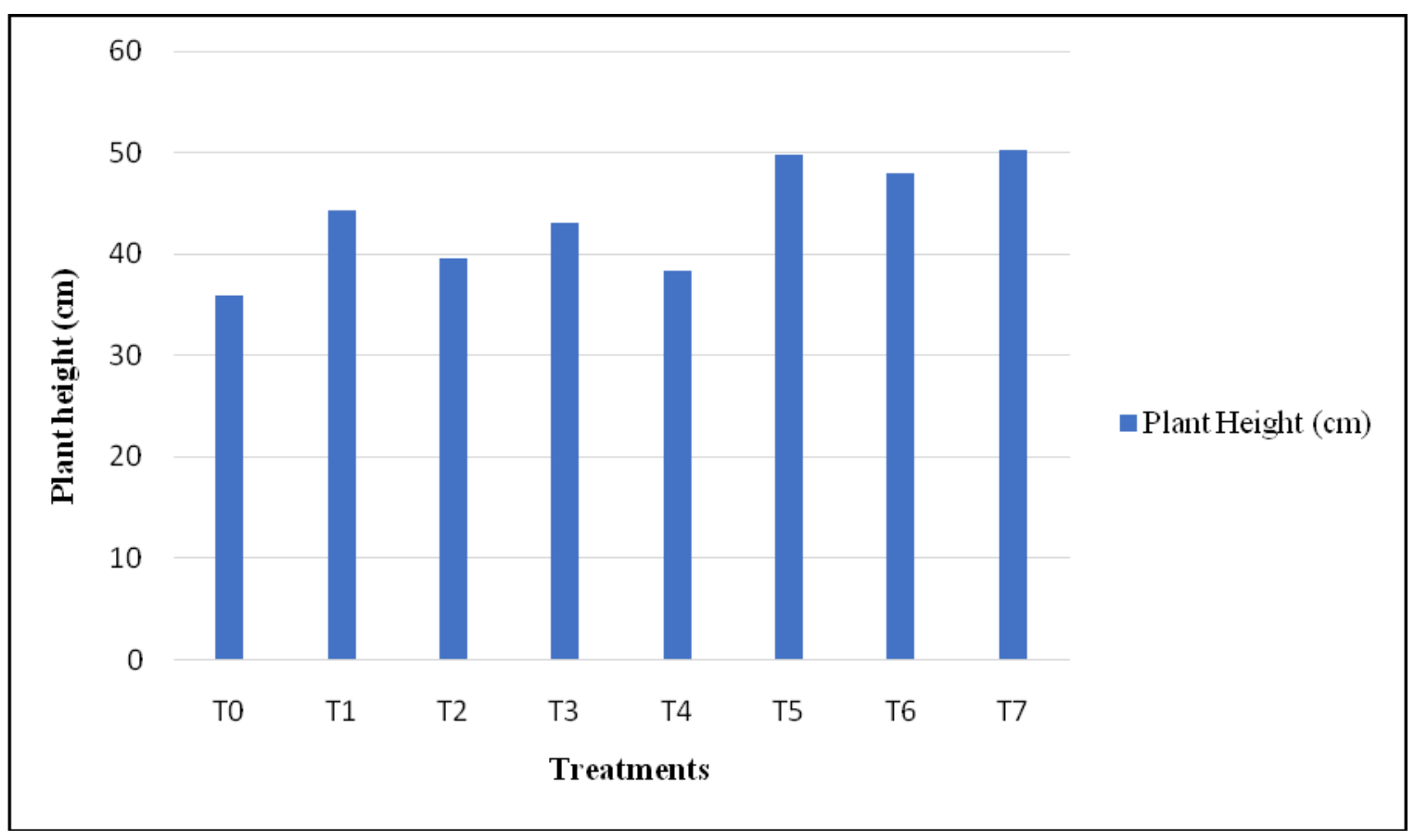


Fig.3 Effect of botanicals and essential oils on root length of Ashwagandha

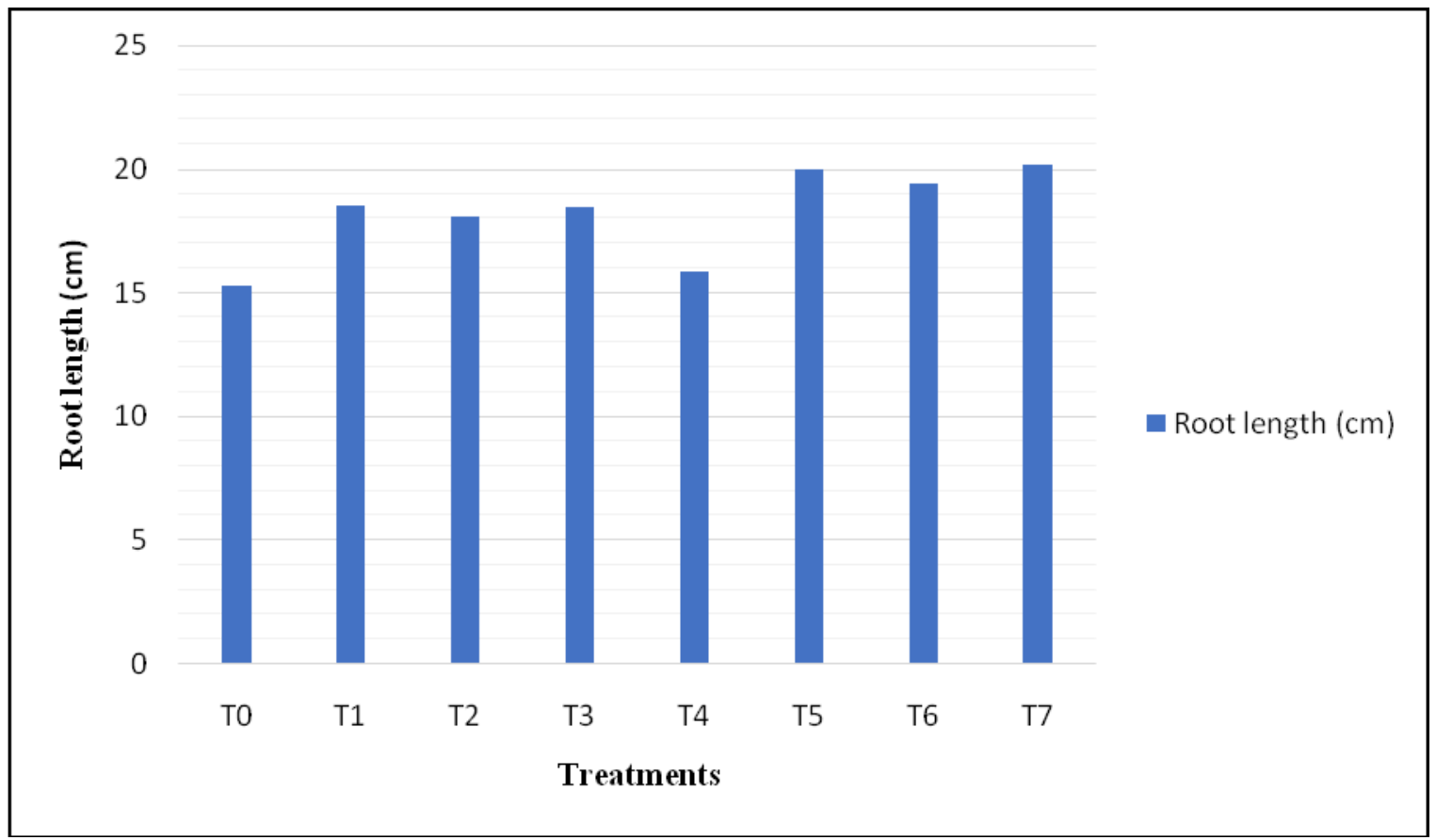

Fig.4 Effect of botanicals and essential oils on dry root weight of Ashwagandha

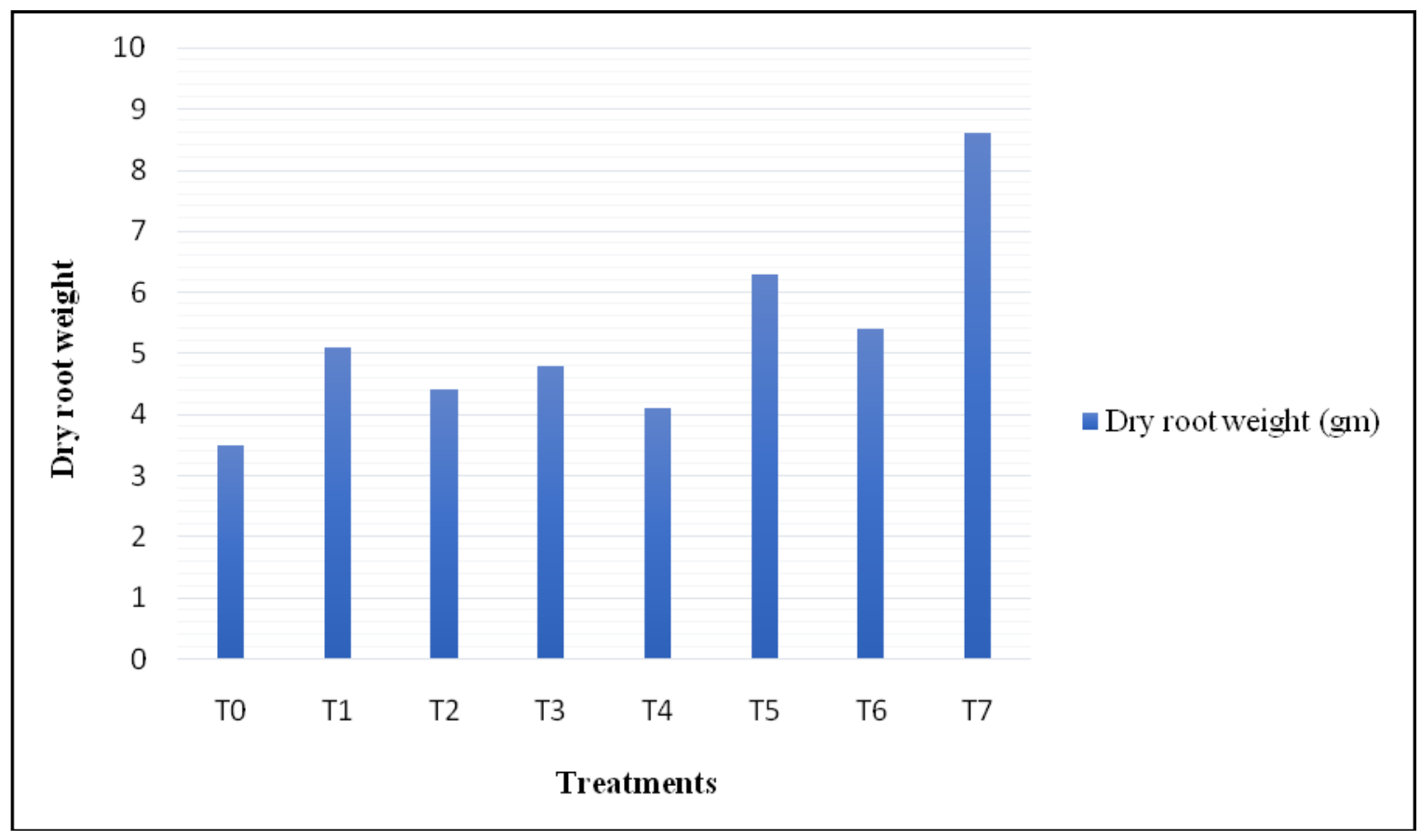


Whereas the peppermint oil contains terpenes which give it antimicrobial properties. The menthone and mentholacetate comprise the main constituents of this oil (Hussain et al., 2001; Singh et al., 2015), they turn the fungal cell membrane permeable, causing the cytoplasmic content (Bhuyan, 2009).

Neem oil was found most effective against Alternaria alternata causing leaf spot disease in Ashwagandha under pot conditions. The studies revealed that the minimum disease incidence (\%) in Ashwagandha after 30, 60 and 90 DAT was observed with Neem oil@ $1.0 \%$. The maximum dry weight of root per plant also observed high with Neem oil. The findings of the present experiment are limited to one crop season under pot conditions (December 2019 to March 2020) under Prayagrajagro-climatic conditions, as such to validate the present findings, more such trials should be carried out in future and also in field conditions.

\section{Acknowledgement}

The authors are grateful to the Head, Department of Plant Pathology, Naini Agriculture Institute, SHUATS for providing the necessary facilities to carry out the present work.

\section{References}

Asthana, R. and Raina, M. K. (1989). Pharmacology of Withania somnifera (L) Dunal.A Review. Indian Drugs. 26:199-205.

Gupta, S., Kumar, A. and Thakur, R. N. (1993). Some problems in cultivation of Withania somnifera(L.) Dunal (Ashwagandha) in Jammu region of India. Journal of Research and Education in Indian Medicine. 33:234235.

Nagraj, S. D. and Reddy, S. N. R. (1985).
Pests infesting Withania somnifera(L.)

Dunal and biology of Epilachnavigintioctopunctata. Indian Drugs Journal. 22:264.

Pati, P. K., Sharma, A. and Vats, S. K. (2008). Post-infection dynamics of leaf spot disease in Withania somnifera. Annals of Applied Biology.165(3)429-440.

Bharti, N., Barnawal, D., Awasthi, A., Yadav, A., and Kalra, A. (2013). Plant growth promoting rhizobacteria alleviate salinity induced negative effects on growth, oil content and physiological status in Mentha arvensis. Acta Physiologiae Plantarum. 36.45-60.

Kinney, M. C. (1923). Influence of soil temperature and misture on infection of wheat seedlings by Helminthosporium sativum. J. Agriculture Research. 26:195-217.

Hussain, A I., Anwar, F., Nigan, P F., Ashraf, M. and Gilani, A. (2001). Seasonal variation in content, chemical composition and antimicrobial and cytotoxic activities of essential oils from four mentha species. Journal of Food Science and Technology. 90(1):1827-1836.

Brahmachari, G. (2004) Neem-An Omnipotent Plant: A Retrospection. Chemical Biology and Drug Design Chem. 5: 408-421.

Bhuyan, P. D., Pathak, M G., Sarma, T. C. and Boruah, P. (2009). Antifungala activity and chemical composition of Citrus reticulata Blanco essential oil against phytopathogens from North East India. Journal of Food Science and Technology. 42:777-780.

Dubey, R. C., Kumar, H. and Pandey, R. R. (2003) Fungitoxic effect of Neem extracts on growth and sclerotial survival of Macrophominaphaseolina in vitro. Journal of American Science. 5(5): 17-24.

Franca, K. R. S., Silva, T. L., Cardoso, T. A. 
L., Ugulino, A. L. N., Rodgiues, A. P. M. and De Mendonca Junior, A. F. (2018). In vitro effect of essential oil of peppermint (Mentha $x$ piperita L.) on the mycelial growth of Alternaria alernata. Journal of Experimental Agricultural International. 26:1-7.

Rawat, Kanchen., Uttam, Kumar. Sahoo., Nagaraj, Hegde. and Awadhesh, Kumar. (2017). Effectiveness of Neem (Azadirachta indica A. Juss) Oil against Decay Fungi. Science and Technology Journal. 5(1):2321-3388.

Tewari D. N (1992) Monograph of Neem Azadirachta indica A. Juss, International Book Distributor, Dehradun, India p: 287.

Singh, R., Muftah, A. M. S. and Belkheir, A. (2015). Antibacterial and antioxidant activities of Menthapiperita L. Arab. Journal of Chemistry. 8(3):322-328.

\section{How to cite this article:}

Prashanth Kumar, M. and Sunil Zacharia. 2021. Efficacy of Botanicals and Essential Oils in the Management of Alternarial Leaf Spot of Ashwagandha (Withania somnifera L. Dunal). Int.J.Curr.Microbiol.App.Sci. 10(04): 171-179. doi: https://doi.org/10.20546/ijcmas.2021.1004.016 